\title{
PENGARUH MOTIVASI KERJA TERHADAP KUALITAS PELAYANAN DIKANTOR KECAMATAN MAPPAKASUNGGU KABUPATEN TAKALAR
}

\author{
Roy $^{1}$, Lukman Hakim ${ }^{2}$, Nurbiah Tahir $^{3}$ \\ 1,2,3 Universitas Muhammadiyah Makassar \\ e-mail : roy@gmail.com
}

\begin{abstract}
This study purposed to find out and analyze the effect of work motivation on service quality in Mappakasunggu District office of Takalar Regency. This study used descriptive research by using quantitative methods and approaches that described work motivation towards service quality in the District Office of Mappakasunggu, Takalar Regency, as many as 77 people. Sampling technique used simple random sampling. The statistical analysis of the coffisien model table, explaining the magnitude of the correlation or relationship $(R)$ value of 0.590. The influence of the independent variable or work motivation $(X)$ on the dependent variable of service quality $(Y)$ shown by the standard coffisien of 0.5 or $59 \%$ based on these results it could be said that the influence of the independent variable or work motivation $(X)$ on the variable the dependent quality of service $(Y)$ in the Mappakasunggu District Office of Takalar Regency was 0.5, or 59\%.
\end{abstract}

Keywords: Motivation, Service Quality

\begin{abstract}
Abstrak
Penelitian ini bertujuan untuk mengetahui dan menganalisis pengaruh motivasi kerja terhadap kualitas pelayanan di kantor Kecamatan Mappakasunggu Kabupaten Takalar. Adapun Jenis penelitian yang digunakan adalah penelitian deskriptif dengan menggunakan metode dan pendekatan kuantitatif yang menggambarkan motivasi kerja terhadap kualitas pelayanan di Kantor Kecamatan Mappakasunggu Kabupaten Takalar yaitu sebanyak 77 orang. Penarikan sampel dalam penelitian menggunakan simple random sampling. Berdasarkan hasil analisis data statisik tabel model coffisien, menjelaskan besarnya nilai korelasi atau hubungan (R) sebesar 0,590. Dari besar pengaruh variabel independen atau motivasi kerja $(\mathrm{X})$ terhadap variabel dependen kualitas pelayanan (Y) ditunjukkan oleh nilai standart coffisien sebesar 0,5 artinya $59 \%$ berdasarkan hasil tersebut maka dapat dikatakan bahwa besar pengaruh variabel independen atau motivasi kerja $(\mathrm{X})$ terhadap variabel dependen kualitas pelayanan (Y) di Kantor Kecamatan Mappakasunggu Kabupaten Takalar sebesar 0,5 yang artinya 59\%.
\end{abstract}

Kata Kunci : Motivasi Kerja, Kualitas Pelayanan

\section{PENDAhUluan}

Pemerintah pada hakikatnya merupakan pelayan bagi masyarakat. Pengadaan pemerintah bukan untuk melayani dirinya sendiri, tapi juga untuk melayani kebutuhan masyarakat. Karena itu birokrasi publik memiliki kewajiban dan bertanggung jawab atas pemberian pelayanan yang baik kepada masyarakat. Dengan demikian pelayanan publik dapat diartikan sebagai pemberian layanan kepada masyarakat secaraprofessional, efektif, efesien, sederhana, transparan, tepat waktu, dan tidak berbelit belit. untuk memenuhi kebutuhan masyarakat secara maksimal.
Salah satu faktor penting dalam pemberian pelayanan publik adalah menumbuhkan motivasi kerja di kalangan pegawai agar pegawai dapat lebih giat dan semangat di dalam memberikan pelayanan kapada masyarakat.Motivasi merupakan suatu upaya yang di lakukan guna memberikan dorongan kepada pegawai untuk dapat lebih giat dalam bekerja, agar dapat tercapai pemberian pelayanan yang maksimal terhadap masyarakat. Untuk dapat menumbuhkan motivasi kerja pegawai maka harus di penuhi kebutuhan pagawai tersebut sehinggapara pegawai lebih termotivasi dalam menjalankan 
fungsi memberikan pelayanan kepada masyarakat.

Pemberianpelayanan merupakan suatu proses pemenuhan kebutuhan melalui kegiatan orang lain secara langsung. pemenuhan kebutuhan tersebut di lakukan oleh suatu organisasi atau lembaga yang memiliki fungsi sebagai pemberi pelayanan. Pemberian pelayanan tersebut di tujukan agar terpenuhinya kebutuhan- kebutuhan masyarakat.

Kantor Kecamatan Mappakasunnggu Kabupaten Takalar, merupakan kantor yang terletak di Kabupaten Takala, Kantor tersebut sama halnya dengan kantor-kantor camat pada umumnya dimana hampir setiap hari menyelenggarakan pemberian pelayanan kapada masyarakat kecamatan. pemberian pelayanan di jalankan berdasarkan aturan yang berlaku dan pedoman kerja pegawai. Para pegawai menjalankan tugas dan fungsinya masing masing sesuai dengan pangkat dan jabatan yang di milikinya. Di jam-jam kerja tidak sedikit biasanya masyarakat yang datang dengan berbagai keperluan. Hal demikian memberikan tugas bagi para pegawai untuk dapat memenuhi tiap-tiap kebutuhan yang di perlukan oleh masyarakat. Hal tersebut menyebabkan pihak kantor Kecamatan Mappakasunggu Kabupaten Takalar, mengangkat pegawai honorer sebagai tenaga pembantu untuk memberikan pelayanan yang baik bagi masyarakat guna terpenuhinya kebutuhan masyarakat secarah maksimal.

Berdasarkan hasil observasi awal peneliti, menemukan bahwa pemberian pelayanan di Kantor Kecamatan Mappakasunggu Kabupaten Takalar masih jauh dari kata maksimal. Hal demikian di sebabkan berbagai faktor antara lain, kebanyakan pegawai datang terlambat dan pulang cepat sehingga waktu yang di gunakan di kantor untuk memberikan pelayanan pada masyarakat sangat tidak mencukupi. Hal ini menyebabkan terkadang masyarakat yang datang ke kantor untuk mendapatkan pelayanan yang dibutuhkan, terkadang tidak dilayani, sebab pegawai yang bersangkutan dengan kebutuhan yang dibutuhkan oleh masyarakat tersebut belum datang ataupun ada yang sudah pulang. Dan bukan hanya itu saja, berbagai kendala terjadinya pelayanan yang tidak maksimal di Kantor KecamatanMappakasunggu Kabupaten Takalar, adalah semangat kerja para pegawai yang sangat begitu kurang sehingga pelayanan yang diberikan cenderung tidak efektif dan efesien.

Manajemen pelayanan publik, adalah suatu proses penerapan ilmu atau seni mengatur atau mengelolah sumberdaya alam dan sumberdaya lainnya secara efektif dan efesien. Untuk membuat rencana, melaksanakan rencana, mengoordinasikan rencana dan menyelesaikan aktivitas-aktivitas pemberian pelayanan demi tercapainya tujuan pemberian pelayanan. Atau dapat dikatakana bahwa, manajemen pelayanan publik merupakan suatu proses perencanaan dan pelaksanaan serta mengarahkan atau mengkoordinasikan penyelesaian aktivitasaktivitas pelayanan publik demi tercapainya tujuan-tujuan pelayanan publik yang telah ditetapkan. Moenir. (2014).

Manajemen Pelayanan Publik merupakan suatu upaya untuk mengatur atau mengelolah berbagai aspek (manajemen) dalam proses mempersiapkan, menyediakan atau menyerahkan, barang dan jasa kepada masyarakat, serta memberikan pengawasan terhadap perkembangannya, dan menindaklanjutinya jika diperlukan. Rahmat Ainur Rohan. (2010).

Berdasarkan penjalasan di atas maka dapat di artikan bahwa manajemen pelayanan pablik merupakan suatu penerapan ilmu atau seni mengatur atau mengelola sumber daya manusia dan sumbar daya lainnya dengan harapan demi tercapainya pelayanan yang maksimal untuk pemenuhan kebutuhan masyarakat.

Motivasi adalah suatu tujuan atau daya penggerak, yang menjadi sumber tenaga atau daya pendorong utama bagi seseorang untuk melakukan aktivitas-aktivitas didalam mendapatkan atau mencapai apa yang diinginkannya baik itu secara positif ataupun negatif. Adapun istilah motivasi berasal dari Bahasa Inggris yaitu, motivation yang dapat di artikan sebagai motif atau alasan dan tujuan seseoran melakukan suatu pekerjaan. Namun perkataan asalnya adalah motive yang juga telah digunakan dalam Bahasa Melayu yaitu kata motif yang berarti tujuan atau segala upaya untuk mendorong seseorang untuk melakukan sesuatu.Secara ringkas dan tepat, Selain itu, Pengertian Motivasi merupakan suatu perubahan yang terjadi pada diri seseorang yang muncul dikarenakan adanya gejala perasaan, kejiwaan dan emosi sehingga mendorong individu untuk melakukan atau 
bertindak sesuatu yang disebabkan karena kebutuhan, keinginan dan tujuan.

Morgan (Hamalik 2002) memberikan pengjelasan terkait motivasi yakni, motivasi saling terikat dengan tiga hal. Ketiga hal tersebut adalah " tingkah laku yang didorong oleh keadaan (motivated behavior), keadaan yang mendorong tingkah laku (motivationg states) dan tujuan daripada tingkah laku tersebut (good or ends of such behavior). Sependapat dengan Morgan, lebih lanjut Hamalik (2002: 173-174) memaparkan bahwa "motivasi adalah suatu perubahan energi di dalam peribadi seseorang yang ditandai dengan timbulnya afektif dan reaksi untuk mencapai tujuan". Pendapat Hamalik, mengandung tiga unsur yang saling berkaitan antara satu dengan yang lainnya yaitu :1) motivasi ditandai dengan timbulnya perasaan (affective aronsal). 2) motivasi dimulai dari adanya perubahan energi dalam diri pribadi. 3) motivasi ditandai oleh reaksi-reaksi untuk mencapai tujuan.

Menurut Maslow (Handoko 1996) ia mengemukakan bahwa manusia di tempat kerjanya dimotivasi oleh suatu keinginan untuk memuaskan berbagai kebutuhan yang ada dalam diri seseorang. Lebih jauh Maslow mengemukakan pembagian tingkatan kebutuhan manusia. Kebutuhan manusia terdiri dari kebutuhan fisiologis, kebutuhan rasa akan keaman, kebutuhan sosial, kebutuhan penghargaan atau apresiasi, dan kebutuhan aktualisasi diri.

Teori motivasi Herzberg (Siagian 2016).Teori ini di kenal sebagai teori $\mathrm{M}-\mathrm{H}$ atau di kenal sebagai teori dua faktor, teori ini memberikan penjalasan pada manajer terkait bagaimana cara mengendalikan faktor-faktor yang bisamenghasilkan kepuasan kerja dan ketidakpuasan kerja. Berdasarkan penelitian yang telah di lakukan maka telah dirumuskan dua faktor yang mempengaruhi kepusan kerja dan ketidakpuasan kerja seseorang dalam organisasi, yaitu "motivasi". Telah di kemukakan bahwa motivasi yang menjadi yang sumber kepuasan kerja adalah prestasi, promosi, penghargaan dan tanggung jawab. Dan Kelompok faktor kedua adalah "iklim baik" dikemukakan bukan sebagai sumber kepuasan kerja tetapi sebagai sumber ketidakpuasan kerja. Faktor ini meliputi antara lain kondisi kerja, hubungan antar pribadi, teknik pengawasan dan gaji. Di jelaskan lebih jauh bahwa perbaikan faktor ini akan mengurangi ketidakpuasan kerja, tetapi tidak akan menimbulkan dorongan kerja. Dengan kata lain Faktor "iklim baik" tidak akan menimbulkan motivasi, tetapi tidak adanya faktor ini akan menjadikan tidak berfungsinya faktor "motivasi".

Berdasarkanpenjelasan tersebut maka dapat di katakan bahwa motivasi merupakan suatu upaya yang di lakukan untuk memberikan dorongan atau meningkatkan kemauan kerja seseorang agar dapat bekerja semaksimal mungkinsehinggga pekerjaan yg di hasilkan dapat sesuai dengan yang di harapkan.

Kualitas pelayanan publik adalah upaya pemerintah dalam menciptakan kepuasan bagi masyarakat di dalam mendapatkan pelayanan, apabila masyarakat merasa puas terhadap pelayanan publik yang di berikan oleh pemerintah maka dapat dikatakan bahwa pemerintah telah melaksanakan tugas dan fungsinya sebagai pelayan bagi masyarakat. Pemberikan pelayanan bagi masyarakat yang menjadi tugas dan fungsi pemerintah tersebut tentu harus memiliki kualitas yang telah di tetapkan.Definisi mengenai kualitas sebagai berikut:"Kualitas merupakan suatu kondisi atau keadaan yang dinamis yang berhubungan dengan produk barang, jasa, proses, lingkungan, dan manusia yang memenuhi atau melebihi harapan."Berdasarkan beberapa definisi kualitas pelayanan diatas maka dapat disimpulkan bahwa kualitas pelayanan adalah merupakan suatu kemampuan untuk menyesuaikan antara pelayanan yang di berikan dengan layanan yang di butuhkan oleh masyarakat.

Menurut Tangkilisan (2005:219). Mengemukakan indikator kualitas pelayanan yaitu : 1) Kesempakan fisik (Tangible) merupakan hal yang berkenaan dengan fasilitas yakni apakah sudah sesuai dengan yang di butuhkan. 2) Reliabilitas(Reliability) merupakan hal yang berkaitan dengan tanggung jawab dimana kesiapan untuk mempertanggung jawabkan informasi yang di berikan. 3) Responsivitas (Responsiveness) merupakan hal yang berkenaan dengan sejauh mana kesigapan daya tanggap serta respon. 4) Kompetensi(Competence) merupakan hal yang berkaitan dengan kemampuan petugas terkait tugas dan jabatannya. 5) Kesopanan (Courtesy) merupakan hal yang berkenaan dengan sikap petugas dalam melayani masyarakat. 6) Kredibilitas(Credibility) merupakan hal yang 
berkenaan dengan situasi kantor terkait biaya serta keberadaan petugas dalam jam kerja. 7) Keamanan(Security); merupakan hal yang berkenaan dengan pemberian jaminan atas rasa aman dan nyaman masyarakat yang dating.

8) Akses(Akses) merupakan hal yang berkenaan dengan kemudahan masyarakat dalam mendapatkan informasi dan kemudahan akses pelayan. 9) Komunikasi(Communication) merupakan hal yang berkaitan dengan kemudahan dalam berkomunikasi dengan petugas serta kemudahan mendapatkan informasi. 10) Pengertian (Understanding the customer) merupakan hal yang berkenaan dengan sikap petugas dalam memahami tiap masalah-masalah yang di adukan oleh masyarakat.

\section{METODE}

Penelitian ini menggunakan jenis penelitian kuantitatif dengan tipe penelitian deskriptif. Populasi dalam penelitian ini berjumlah 3850 orang yang terdiri dari 20 orang pegawai pada Kantor Kecamatan Mappakasunggu Kabupaten Takalar dan 3830 orang dari masyarakat Kecamatan Mappakasunggu Kabupaten Takalar.Uji validitas dilakukan untuk menguji keakuratan/ kevalidan kuesioner penelitian, sedangkan uji reliabilitas dilakukan untuk menguji kehandalan/ konsistensi kuesioner penelitian. Peneliti akan melakukan uji validitas dengan menggunakan bantuan software SPSS version 24.0. Pengujian validitas cukup dengan membandingkan nilai $r_{\text {hitung }}$ dengan nilai $r_{\text {tabel }}$ Product Moment (lihat Lampiran). Jika nilai $r_{\text {hitung }} \geq r_{\text {tabel }}$ maka indikator atau pertanyaan kuesioner dikatakan valid, begitupula sebaliknya. Data juga dikatakan valid jika nilai sig. (2-tailed) data $<0.05$.

Peneliti akan melakukan uji reliabilitas dengan menggunakan bantuan software SPS version 24.0. Pengujian realibilitas cukup dengan membandingkan $r_{\text {alpha }}$ atau angka cronbach alpha dengan nilai 0,7.Jika $r_{\text {alpha }}$ atau angka cronbach alpha $\geq 0,7$ maka indikator atau pertanyaan kuesioner dikatakan reliabel, begitupula sebaliknya.

Penelitian ini menggunakan beberapa teknik analisis data, yaituTeknik analisis statistik deskriptif yang akan digunakan dalam penelitian ini berupa tabel, perhitungan modus, median, mean (pengukuran tendensi sentral), perhitungan penyebaran data melalui perhitungan rata-rata dan standar deviasi, serta perhitungan persentase (\%).

\section{HASIL DAN PEMBAHASAN}

Data yang di peroleh selama penelitian pada Kantor Kecamatan Mapppakasunggu Kabupaten Takalar. Data ini di peroleh peneliti dari kuesioner yang telah di bagikan Pada 77 responden di Kecamatan Mappakasunggu Kabupaten Takalar. Kuesioner yang dibagikan terdiri dari 2 variabel yaitu: variabel $X$ pengaruh motivasi dan variabel $\mathrm{Y}$ kualitas pelayanan. Yang di berikan pada Kecamatan Mappakasunggu. Penyajian data meliputi datadata tentang identitas dan distribusi jawaban responden di Kecamatan Mappakasungu terhadap pertanyaan maupun pernyataan yang di ajukan yang akan diuraikan dalam tabel frekuensi.

Penelitian tentang pengaruh motivasi kerja terhadap kualitas pelayanan Di Kantor Kecamatan Mappakasunggu Kabupaten Takalar. Dilaksanakan pada tanggal 16 November 2019 s/d 16 januari 2020. Adapun yang menjadi responden pada penelitian ini adalah pegawai pada Kantor Kecamatan Mappakasunggu Kabupaten Takalar dan masyarakat Kecamatan Mappakasunggu Kabupaten Takalar dengan jumlah total responden yaitu Sebanyak 77 orang.

\section{Prestasi}

Prestasi Merupakan suatu pencapaian yang baik dari hasil usaha yang telah di lakukan oleh pegawai Kecamatan Mappakasunggu dalam melaksanakan tugas dan fungsinya yang sangat erat kaitannya dengan kualitas kerja, kuantitas kerja, keandalan, dan sikap pegawai.

Hasil analisis deskriptif tentang indikator prestasi maka dapat dilihat bahwa penilaian rata-rata responden yang paling tinggi adalah yaitu penilaian setuju dengan jumlah sebesar $54,26 \%$ sedangkan penilaian rata-rata responden paling rendah yakni penilaian tidak setuju dengan jumlah sebesar 2,20\%. Dengan demikian dapat di katakan bahwa jummlah responden yang memberikan penilaian sangat baik yaitu sebesar $88,84 \%$ responden menjawab sangat baik, hasill penilaian tersebut di peroleh dari hasil analisis indikator prestasi sebesar 34,58\% responden yang memilih sangat setujuh dan dijumlah dengan $54,26 \%$ 
responden yang memilih setuju. Namun dengan demikian masih ada responden yang menyatakan kurang baik dengan jumlah sebesar $11,16 \%$ hasil tersebut diperoleh dari penilaian responden yang menyatakan raguragu dengan jumlah sebesar 8,30 dan di jumlah dengan hasil penilaian responden yang memilih tidak setuju dengan jumlah sebesar 2,86\%.

Pernyataan diatas merupakan hasil observasi yang diperoleh oleh peneliti dilapangan, bahwa prestasi pegawai Dikantor Kecamatan Mappakasunggu Kabupaten Takalar. Sangat baik dari segi kualitas kerja,kuantitas kerja,keandalan yang mendapatkan respon sangat baik dari segi penilaian responden. Berdasarkan hasil penelitian tersebut menunjukkan bahwa indikator prestasi berada pada penilaian sanagat baik dengan memeperoleh hasil sebesar $88,84 \%$ tingkat penilaian tersebut diperoleh sangat baik berdasarkan tabel 3.1 yaitu tabel kriteria jawaban responden.

\section{Penghargaan}

Penghargaan merupakan pemberian bentuk apresiasi kepada seorang pegawai atas pencapaian yang telah di raihnya yang dinilai sangat baik.Hal tersebut dapat dinilai dari segi tingkat kesuksesan dalam bekerja, tingkat pemahaman dan pengetahuan, dan ketepatan dalam bekerja.

Hasil analisis deskriptif tentang indikator penghargaan dapat di lihat dengan bahwa nilai rata-rata responden paling tinggi yakni penilaian setuju dengan jumlah sebesar $61 \%$ sedangkan jumlah penilaian terendah nilai ratarata responden yakni berada pada penilaian tidak setuju dengan jumlah sebesar $1,3 \%$. Berdasarkan data tersebut menunjukkan bahwa penilaian responden yang tertinggi di peroleh yakni sangat baik dengan jumlah penilaian responden yakni sebesar $91,68 \%$ penilaian tersebut diperoleh dari hasil analisis indikator penghargaan sebesar $30,68 \%$ responden menjawab sangan setuju, kemudian nilai tersebut ditambahkan dengan nilai rata-rata responden yang menjawab setuju dengan dengan jumlah sebesar $61 \%$. Namun dengan begitu masih ada responden yang menjawab kurang baik denagan jumlah sebesar $8,32 \%$ nilai tersebut diperoleh dari penilaian responden yang ragu-ragu sebesar 7,02\% kemudian ditambahkan dengan jumlah penilaian responden yang menjawab tidak setuju sebesar $1,3 \%$.

Pernyataan diatas merupakan hasil observasi peneliti di lapangan, bahwa indikator penghargaan mendapatkan tanggapan yang baik dari responden. Berdasarkan hasil penelitian tersebut menunjukkan bahwa indikator penghargaan berada pada tingkat penilaian sangat baik dengan memperoleh hasil sebesar 91,68\% tingkat penilaian tersebut di katakan sangat baik dapat diketahui dari tabel 3.1 yaitu tabel kriteria jawaban responden.

\section{Promosi}

Promosi merupakan Pemberian kenaikan jabatan kepada seorang pegawai Kecamatan Mappakasunggu dari jabatan yang rendah ke jabatan yang tinggi.Misalnya apabila ada seorang pegawai yang memiliki kemampuan yang lebih dari jabatan yang di milikinya dan pantas untuk mendapatkan jabatan yang lebih dari yang di dapatkannyasekarang maka pantas untuk di promosikan baik secara sementara, tetap, kecil dan promosi kering.

Hasil analisis deskriptif tentang indikator promosi pada variabel motivasi kerja dapat dilihat bahwa penilaian rata-rata responden palimg tinggi dengan jumlah sebesar yakni $59,96 \%$ responden memilih setuju. Sedangkan penilaian rata-rata responden paling rendah berda pada penilaianTidak setuju dengan jumlah sebesar $0,78 \%$. Hal ini menunjukkan bahwa penilaian responden sangat baik berjumlah sebesar $88,04 \%$ hasil penilaian tersebut diperoleh dari hasil analisis penilaian responden terhadap indikator promosi dimana jumlah responden yang menjawab sangat setuju sebesar $28,08 \%$ nilai tersebut kemudian aitambahkan dengan hasil penilaian responden yang menilai setuju sebesar 59,96\%. Namun demikian masih ada responden yang menjilaikurang baik dengan jumlah sebesar $11,96 \%$ nilai tersebut diperoleh dari hasil penilaian responden ynag memilih ragu-ragusebesar $11,18 \%$ nilai tersebut kemudian ditambahkan dengan penilaian responden yang memilih tidak setuju dengan jumlah sebesar $0,78 \%$.

Pernyataan diatas merupakan hasil obsrvasi peneliti dilpangan, bahawa indikator promosi mempunyai peniilaian yang baik dari responden . berdasarkan hasil penelitian tersebut menuunjukkan bahwa indikator 
promosi berada pada tingkat penilaian sangat baik, dengan memperoleh hasil sebesar 88,04\% tingkat penilaian tersebut dikatakan sangat baik dapat diketahui dari tabel 3.1 yaitu tabel kriteria jawaban responden.

\section{Tanggung jawab}

Tanggung jawab adalah kesadaran para pegawai Kecamatan Mappakasunggu akan tingkah laku atau perbuatan yang di sengaja maupun yang tidak di sengaja. Misalnya kesadaran para pegawai akan tugas yang di milikinya maka pegawai tersebut senantiasa sepenuh hati dan selalu melakukan yang terbaik dalam menjalankan tugas-tugasnya. Tanggung jawab tersebut dapat dilihat dari segi kesadaran atasas tugas dan fungsinya, ketaatan pegawai pada aturan dan pegawai selalu ada pada saat jam kerja.

Hasil analisis deskriptif tentang indikator tanggung jawab pada variabel motivasi kerja dapat dilihat bahwa penilaian rata-rata responden palimg tinggi dengan jumlah sebesar yakni $58,66 \%$ responden memilih setuju. Sedangkan penilaian rata-rata responden paling rendah berada pada penilaianTidak setuju dengan jumlah sebesar $1,3 \%$. Hal ini menunjukkan bahwa penilaian responden sangat baik berjumlah sebesar $89,34 \%$ hasil penilaian tersebut diperoleh dari hasil analisis penilaian responden terhadap indikator tanggung jawab dimana jumlah responden yang menjawab sangat setuju sebesar 30,68,\% nilai tersebut kemudian ditambahkan dengan hasil penilaian responden yang menilai setuju sebesar $58,66 \%$. Namun demikian masih ada responden yang menilai kurang baik dengan jumlah sebesar 10,66\% nilai tersebut diperoleh dari hasil penilaian responden yang memilih ragu-ragu- sebesar 9,36\% nilai tersebut kemudian ditambahkan dengan penilaian responden yang memilih tidak setuju dengan jumlah sebesar 1,3\%.

Pernyataan diatas merupakan hasil obsrvasi peneliti dilapangan, bahwa indikator tanggung jawab mempunyai penilaian yang baik dari responden . berdasarkan hasil penelitian tersebut menunjukkan bahwa indikator tanggung jawab berada pada tingkat penilaian sangat baik, dengan memperoleh hasil sebesar $89,34 \%$ tingkat penilaian tersebut dikatakan sangat baik dapat diketahui dari tabel 3.1 yaitu tabel kriteria jawaban responden.
Berdasarkan hasil penelitian pada Kantor Kecamatan Mappakasunggu Kabupaten Takalar. Menunjukkan bahwa tingkat motivasi kerja pegawai berdasarkan penilaian yang telah dilakukan oleh 77 responden, berada pada tingkat yang sangat bagus hasil tersebut diperoleh dari penilaian terhadap 4 (empat) indikator motivasi kerja yaitu: prestasi, penghargaan, promosi, dan tanggung jawab. Namun diantara ke 4 (empat) indikator tersebut, yang paling mendapatkan penilaian tertinggi adalah indikator penghargaan dengan jumlah sebesar 91,68\%.

Dengan hasil yang diperoleh pada variabel $\mathrm{X}$ hal tersebut mengambarkan bahwa motivasi kerja pada Kantor Kecamatan Mappakasunggu Kabupaten Takalar Sudah sesuai dengan tujuan standart operasional kantor yang ada. Hal tersebut dibuktikan oleh tanggapan responden terhadap kuesioner yang dibagikan dan saat peneliti berada dilapangan dan melihat langsung keadaan motivasi kerja para pegawai. Semua pegawai sudah menjalankan tugas dan fungsinya dengan baik. Tentu hal ini harus dipertahankan dan harus terus ditingkatkan sehingga masyarakat dapat terlayani lebih baik lagi dan lebih maksimal lagi, motivasi kerja pegawai harus slalu menjadi perhatian didalam menjalankan tugas dan fungsi sebagai pemberi pelayanan bagi masyarakat, semanging tinggi motivasi kerja pegawai maka semaking bagus pula kualitas pelayanan yang diberikan dan tentu hal ini akan menimbulkan rasa kepuasan dari masyarakat.

\section{Reliabilitas (Reliability)}

Reliabilitas Meliputi sejauh mana informasi yang diberikan kepada masyarakat tepat dan dapat dipertanggungjawabkan. Artinya pegawai di Kecamatan Mappakasunggu didalam memberikan pelayanan maka harus sesuai dengan kapasitasnya dan sesuai dengan apa yang di butuhkan oleh masyarakat. Indilator reliabilitas dapat dinilai dari segi keakuratan informasi yang diberikan, minimnya keselahan yang dilakukan, dan kesesuaian pelayanan yang diberikan dengan yang dibutuhkan oleh masyarakat.

Hasil analisis deskriptif tentang indikator reliabilitas pada variabel kualitas pelayanan dapat dilihat bahwa penilaian rata-rata responden palimg tinggi dengan jumlah sebesar yakni $61,52 \%$ responden memilih 
setuju. Sedangkan penilaian rata-rata responden paling rendah berada pada penilaianTidak setuju dengan jumlah sebesar $3,38 \%$. Hal ini menunjukkan bahwa penilaian responden sangat baik berjumlah sebesar $82,58 \%$ hasil penilaian tersebut diperoleh dari hasil analisis penilaian responden terhadap indikator reliabilitas dimana jumlah responden yang menjawab sangat setuju sebesar 21,06,\% nilai tersebut kemudian ditambahkan dengan hasil penilaian responden yang menilai setuju sebesar $61,52 \%$. Namun demikian masih ada responden yang menilai kurang baik dengan jumlah sebesar $17,42 \%$ nilai tersebut diperoleh dari hasil penilaian responden yang memilih ragu-ragu- sebesar $14,04 \%$ nilai tersebut kemudian ditambahkan dengan penilaian responden yang memilih tidak setuju dengan jumlah sebesar 3,38\%.

Pernyataan diatas merupakan hasil obsrvasi peneliti dilapangan, bahwa indikator reliabilitas mempunyai penilaian yang baik dari responden. berdasarkan hasil penelitian tersebut menunjukkan bahwa indikator reliabilitas berada pada tingkat penilaian sangat baik, dengan memperoleh hasil sebesar $82,58 \%$ tingkat penilaian tersebut dikatakan sangat baik.

\section{Responsivitas (Responsiveness)}

Responsivitas Yaitu pegawai Kecamatan Mappakasunggu harus cepat dan tanggap didalammemberikan respon apabila ada permintaan pemberian pelayanan dari masyarakat. Indikator responsivitas dapat dinilai dari segi kecepatan pegawai dalam melayani, efesien dan efektivitas pelayanan serta daya tanggap pegawai terhadap permintaan layanan.

Hasil analisis deskriptif tentang indikator responsivitas maka dapat dilihat bahwa penilaian rata-rata responden yang paling tinggi adalah yaitu penilaian setuju dengan jumlah sebesar $57,36 \%$ sedangkan penilaian rata-rata responden paling rendah yakni penilaian tidak setuju dengan jumlah sebesar 2,86\%. Dengan demikian dapat di katakan bahwa jummlah responden yang memberikan penilaian sangat baik yaitu sebesar $86,84 \%$ responden menjawab sangat baik, hasill penilaian tersebut di peroleh dari hasil analisis indikator responsivitas sebesar $29,12 \%$ responden yang memilih sangat setujuh dan dijumlah dengan
$57,36 \%$ responden yang memilih setuju. Namun dengan demikian masih ada responden yang menyatakan kurang baik dengan jumlah sebesar 13,53\% hasil tersebut diperoleh dari penilaian responden yang menyatakan raguragu dengan jumlah sebesar 10,66\% dan di jumlah dengan hasil penilaian responden yang memilih tidak setuju dengan jumlah sebesar $2,87 \% \%$.

Pernyataan diatas merupakan hasil observasi yang diperoleh oleh peneliti dilapangan, bahwa responsivitas pegawai Dikantor Kecamatan Mappakasunggu Kabupaten Takalar. Sangat baik dari segi kualita pelayanan, kuantitas kerja, keandalan yang mendapatkan respon sangat baik dari segi penilaian responden. Berdasarkan hasil penelitian tersebut menunjukkan bahwa indikator responsivitas berada pada penilaian sanagat baik dengan memeperoleh hasil sebesar $86,84 \%$ tingkat penilaian tersebut diperoleh sangat baik.

\section{Kompetensi}

$\begin{array}{ccc}\begin{array}{c}\text { Kompetensi } \\ \text { kemampuan }\end{array} & \begin{array}{c}\text { Meliputi } \\ \text { petugas }\end{array} & \text { bagaimana } \\ \text { Kecamatan }\end{array}$
Mappakasunggu dalam melayani masyarakat, apakah ada pelatihan untuk meningkatkan kemampuan pegawai sesuai perkembangan tugas. Kemampuan tersebut dapat dinilai dari segi penguasaan pegawai terhadap tugas dan fungsinya, pegawai sangat memahami dan mengerti pekerjaan yang diberikan, dan pegawai sangat bisa diandalkan.

Hasil analisis deskriptif tentang indikator kompetensi pada variabel kualitas pelayanan dapat dilihat bahwa penilaian rata-rata responden palimg tinggi dengan jumlah sebesar yakni $62,56 \%$ responden memilih setuju. Sedangkan penilaian rata-rata responden paling rendah berada pada penilaianTidak setuju dengan jumlah sebesar $2,08 \%$. Hal ini menunjukkan bahwa penilaian responden sangat baik berjumlah sebesar $82,58 \%$ hasil penilaian tersebut diperoleh dari hasil analisis penilaian responden terhadap indikator kompetensi dimana jumlah responden yang menjawab sangat setuju sebesar $20,02 \%$ nilai tersebut kemudian ditambahkan dengan hasil penilaian responden yang menilai setuju sebesar $62,56 \%$. Namun demikian masih ada responden yang menilai kurang baik dengan jumlah sebesar $17,42 \%$ nilai tersebut diperoleh 
dari hasil penilaian responden yang memilih ragu-ragu- sebesar $15,34 \%$ nilai tersebut kemudian ditambahkan dengan penilaian responden yang memilih tidak setuju dengan jumlah sebesar 2,08\%.

Pernyataan diatas merupakan hasil obsrvasi peneliti dilapangan, bahwa indikator kompetensi mempunyai penilaian yang baik dari responden. berdasarkan hasil penelitian tersebut menunjukkan bahwa indikator kompetensi berada pada tingkat penilaian sangat baik, dengan memperoleh hasil sebesar $82,58 \%$ tingkat penilaian tersebut dikatakan sangat baik.

\section{Kesopanan}

Kesopanan yaitu sikap pegawai Kecamatan Mappakasunggu dalam memberikan pelayanan kepada masyarakat yang meliputi tutur kata yang baik, keramahan dan senyuman.

Hasil analisis deskriptif tentang indikator kesopanan pada variabel kualitas pelayanan dapat dilihat bahwa penilaian rata-rata responden palimg tinggi dengan jumlah sebesar yakni $58,66 \%$ responden memilih setuju. Sedangkan penilaian rata-rata responden paling rendah berada pada penilaianTidak setuju dengan jumlah sebesar $3,38 \%$. Hal ini menunjukkan bahwa penilaian responden sangat baik berjumlah sebesar $85,7 \%$ hasil penilaian tersebut diperoleh dari hasil analisis penilaian responden terhadap indikator kesopanan dimana jumlah responden yang menjawab sangat setuju sebesar $\%$ nilai tersebut kemudian ditambahkan dengan hasil penilaian responden yang menilai setuju sebesar 58,66\%. Namun demikian masih ada responden yang menilai kurang baik dengan jumlah sebesar $14,3 \%$ nilai tersebut diperoleh dari hasil penilaian responden yang memilih ragu-ragu sebesar $10,92 \%$ nilai tersebut kemudian ditambahkan dengan penilaian responden yang memilih tidak setuju dengan jumlah sebesar 3,38\%.

Pernyataan diatas merupakan hasil obsrvasi peneliti dilapangan, bahwa indikator kesopanan mempunyai penilaian yang baik dari responden - berdasarkan hasil penelitian tersebut menunjukkan bahwa indikator kesopanan berada pada tingkat penilaian sangat baik, dengan memperoleh hasil sebesar $85,7 \%$ tingkat penilaian tersebut dikatakan sangat baik dapat diketahui dari tabel 3.1 yaitu tabel kriteria jawaban responden.

Berdasarkan hasil penelitian pada Kantor Kecamatan Mappakasunggu Kabupaten Takalar. Menunjukkan bahwa tingkat kualitas pelayanan berdasarkan penilaian yang telah dilakukan oleh 77 responden, berada pada tingkat yang sangat baik, hasil tersebut diperoleh dari penilaian terhadap 4 (empat) indikator kualitas pelayanan yaitu: reliabilitas, responsivitas, kompetensi, dan kesopanan. Namun diantara ke 4 (empat) indikator tersebut, yang paling mendapatkan penilaian tertinggi adalah indikator responsivitas dengan jumlah sebesar $86,84 \%$.

Dengan hasil yang di peroleh pada variabel $\mathrm{Y}$ hal tersebut mengambarkan bahwa kualitas pelayanan pada Kantor Kecamatan Mappakasunggu Kabupaten Takalar. Sudah sesuai dengan tujuan standart operasional kantor yang ada. Hal tersebut dibuktikan oleh tanggapan responden terhadap kuesioner yang dibagikan dan saat peneliti berada dilapangan dan melihat langsung keadaan kualitas pelayanan Dikantor Kecamatan Mappakasunggu Kabupaten Takalar. Semua pegawai sudah menjalankan tugas dan fungsinya dengan baik. Tentu hal ini harus dipertahankan dan harus terus ditingkatkan sehingga masyarakat dapat terlayani lebih baik lagi dan lebih maksimal lagi, kualitas pelayanan harus selalu menjadi perhatian didalam menjalankan tugas dan fungsi sebagai pemberi pelayanan bagi masyarakat, semaking tinggi kualitas pelayanan yang di berikan maka semaking bagus pula tannggapan dari masyarakat dan tentu hal ini akan menimbulkan rasa kepuasan dari masyarakat.

Berdasarkan hasil analisis penelitian motivasi kerja yang diterapkan di Kantor Kecamatan Mappakasunggu Kabupaten Takalar terhadap kualitas pelayanan, dapat dilihat dalam kolom Standardized Coefficients motivasi kerja terhadap kualitas pelayanan tergolong kuat dengan nilai sebesar 0,5 atau59\% yang artinya memiliki pengaruh terhadap motivasi kerja pegawai. Pengaruhnya dapat dikatakan kuat karena lebih besar dari 0,000 atau signifikan. Berdasarkan uji signifikan yang telah diperoleh $t_{\text {hitung }}$ sebesar 24,488 dan $t_{\text {tabel }}$ sebesar2,725 karena $t_{\text {hitung }}>t_{\text {tabel }}$ $(24,488>2,725)$ maka H0 ditolak artinya terdapat hubungan signifikan. Motivasi kerja terhadap kualitas pelayanan dapat dikatakan 
berpengaruh Dikantor Kecamatan

Mappakasunggu Kabupaten Takalar karena motivasi kerja yang diterapkan yaitu prestasi, penghargaan, promosi, dan tanggung jawab. sesuai dengan kondisi kerja atau situasi yang ada di Kantor Kecamatan Mappakasunggu Kabupaten Takalar..

Dari hasil penelitian dan pendapat para ahli dapat disimpulkan bahwa terdapat pengaruh motivasi kerja pegawai terhadap kualaitas pelayanan Dikantor Kecamatan Mappakasunggu Kabupaten Takalar.

Berdasarkan interpretasi data maka dapat dilihat secara jelas bahwa motivasi kerja mempunyai pengaruh yang cukup kuat terhadap kualitas pelayanan pada Kantor Kecamatan Mappakasunggu Kabupaten Takalar. Untuk motivasi kerja dan kualitas pelayanan pada Kantor Kecamatan Mappakasunggu Kabupaten Takalar sudah terlaksanan dengan baik, namun demikian hal tersebut bukan berarti sudah tidak perlu diperhatikan lagi. motivasi kerja harus terus diperhatikan untuk lebih meningkatkan kualitas pelayanan yang diberikan untuk masyarakat pada Kantor Kecamatan Mappakasunggu Kabupaten Takalar. Dalam hal ini pemerintah harus lebih memperhatikan motivasi kerja atau kebutuhan lain yang diperlukan Kantor Kecamatan Mappakasunggu Kabupaten Takalar Karna dapat dikatakan bahwa motivasi kerja cukup mempengaruhi kualitas pelayanan untuk diberikan kepada masyarakat. Dengan adanya motivasi kerja yang tinggi maka dapat memberikan pelayanan yang berkualitas dan hal ini tentu dapat memberikan rasa kepuasan bagi masyarakat yang berkepentingan. Begitu pula sebaliknya jika motivasi kerja pegawai sangat rendah maka, akan mempengaruhi kualitas pelayanan yang diberikan kepada masayarakat.

Berdasarkan hasil penelitian maka dapat diketahui bahwa mativasi kerja yang ada pada Kantor Kecamatan Mappakasunggu Kabupaten Takalar berpengaruh sebesar $34 \%$ terhadap kualitas pelayanan. Hal ini juga ditunjukan pada tabel 4.11 dimana tingkat motivasi kerja pada Kantor Kacamatan Mappakasunggu Kabupaten Takalar berada dalam kategori sangat baik.

\section{KESIMPULAN}

Berdasarkan hasil penelitian yang dilakukan mengenai pengaruh motivasi kerja terhadap kualitas pelyanan Dikantor Kecamatan Mapppakasunggu Kabupaten Takalar. Maka dapat ditarik kesimpulan sebagai berikut: 1) Motivasi kerja pegawai pada Kantor Kecamatan Mappakasunggu Kabupaten Takalar sudah sangat baik, dinilai dari segi prestasi pegawai, promosi pegawai, penghargaan dan tanggung jawab. Tinnginya motivasi pegawai di Kantor Kecamatan Mappakasunggu Kabupaten Takalar. Mendapat apresiasi yang sangat baik dari masyarakat. 2) Kualitas pelayanan pada kantor Kecamatan Mappakasunggu Kabupaten Takalar. Sudah sangat baik, hal tersebut dinilai dari segi responsivitas pegawai, reliabilitas, kompetensi, dan kesopanan, kemampuan yang mempuni serta kualitas pegawai yang sangat bagus didalam melayani masyarakat, mendapatkan tanggapan yang sangat baik dari masyarakat dan menimbulkan rasa kepuasan pada masyarakat. 3)Pengaruh motivasi kerja terhadap kualitas pelayanan Dikantor Kecamatan Mappakasunggu Kabupaten Takalar, berpengaruh sebesar 0,5 artinya $59 \%$ besar pengaruh variabel motivasi kerja $X$ terhadap variabel kualitas pelayanan $\mathrm{Y}$ pada Kantor KecamatanMappakasunggu Kabupaten Takalar. Dari hasil output tersebut berada pada tingkatan sangat berpengaruh.

\section{REFERENSI}

Ahmad Ainur Rohan, Dkk 2010. Reformasi Pelayana Public. Malang Program Sekolah Demokrasi

Arikunto. 2010. Prosedur Penelitian Suatu Pendekatan Praktik. Jakarta Rineka Cipta

H A S Monier. 2008. Manajemen Pelayanan Umum Di Indonesia. Jakarta Bumi Aksara.

Hamalik. 2002. Psikologi Belajar Dan Mengajar. Sinar Baru Algensido. Bandung.

Handoko Hani $T$ Dr. MBA Dan Reksohadiprodjo Sukanto. Dr M Com 1996 Organisasi Perusahaan, Edisi Kedua Yogyakarta. BPFE.

Siagian, Manajemen Sumber Daya Manusia, Jakarta Bumi Aksara. 
Tangkilisan, Heser Nogi, S, 2005, Manajemen Publik, Jakarta PT, Gramedia Widiasarana.

Natalia Tubun. 2014. Pengaruh Motivasi Kerja Tehadap Kualitas Pelayanan Publik Pada Kantor Kecamatan Long Iram Kabupaten Kutai Barat.Universitas Samarinda.

Qonita 2012. Motivasi Kreja Utama Petani Dalam Kemitraaan Dengan Pusat Pengelolaan Kelapa Terpadu Di Kabupaten Progo. Universitas Di Ponerogo Semaran. 